\title{
Die opbou van 'n missionale gemeente: 'n Verkenning van die invloed van Godsbegrip en liturgiese ervaring
}

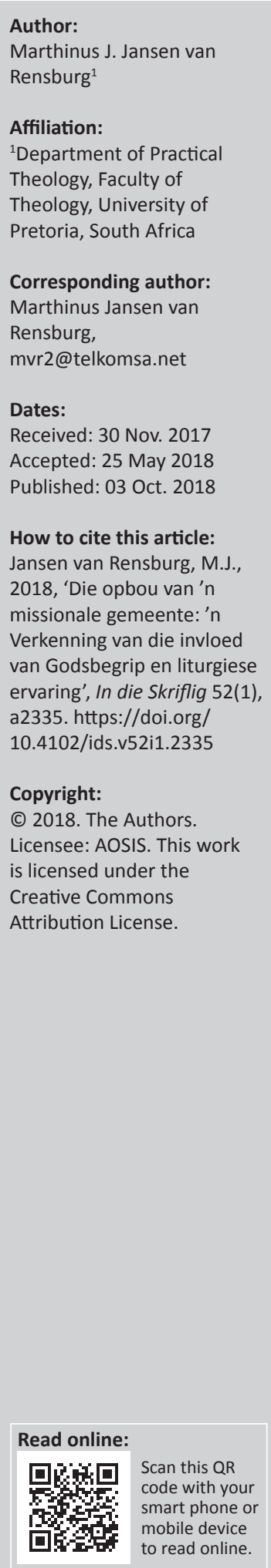

\begin{abstract}
The building up of a local missional congregation: The understanding of God and liturgy. The purpose of this article is to investigate the understanding of God by members of the Netherdutch Reformed Church (Nederduitsch Hervormde Kerk van Afrika [NHKA]), their liturgical experience and its influence on the development of a missional congregation. The world is currently in the midst of a wave of changes that have far-reaching implications for the church and, specifically, for the NHKA. In a changing world it is imperative that church members understand the value of the different metaphors of God as well as its value for the development of the missional congregation. From a practical-theological approach, this article aims to look at the influence of the liturgy of life on the development of a missional congregation.
\end{abstract}

\section{Inleiding}

Hoe effektief vind gemeentebou in die NHKA plaas? Slaag plaaslike gemeentes daarin om hulleself op te bou? Hoe ervaar lidmate die eredienste van die NHKA? Is die bywoon van eredienste noodsaaklik om God te aanbid? Hoe lyk lidmate se verstaan van God? Hoe effektief is die NHKA se missionale gerigtheid?

Met hierdie vrae vind ons aansluiting by dié van Osmer (2008:4): 'What is going on?' en 'Why is this going on?' Die empiriese navorsing wat in die NHKA gedoen is, het ten doel om die huidige situasie te verstaan en te verklaar. Osmer (2008:4) se vraag, 'What ought to be going on?' plaas die fokus op die impak van verandering en die noodsaaklikheid daarvan om ' $n$ antwoord te vind op die vraag, 'How might we respond?' (p. 4). Hierdie vraag kulmineer in 'n nuwe praktykteorie wat lidmate se Godsbeelde en die invloed daarvan op die liturgiese opbou van die missionale gemeentes van die NHKA omvat. Die perspektiewe van gemeentebou is as vertrekpunt gebruik in die teologiese besinning oor die trinitariese oorsprong van die kerk (Nel 2015:49).

Lidmate se verstaan van God was die essensiële vertrekpunt van hierdie navorsing. Daar is ook ondersoek ingestel of daar 'n beduidende verskil tussen gesinslede se verstaan van God is. Die onderstaande tabel dui hulle response aan.

Dit is dus uit Tabel 1 se gegewens duidelik dat lidmate ' $n$ baie positiewe beeld ... nie ' $n$ betekenisvolle verskil in gesinslede se verstaan van God is nie.

Met die baie positiewe respons op lidmate se beeld van God het die navorsing na erediensbywoning verskuif, aangesien dit 'n baie belangrike plek in gemeentes se funksionering inneem (Nel 2015:18).

Die respondente se reaksie op die vraag of bywoning van eredienste as noodsaaklik beskou word, word in die onderstaande tabel saamgevat:

Die volgende kan uit Tabel 2 se gegewens afgelei word:

- $57.36 \%$ van die respondente is van mening dat eredienste noodsaaklik is om God te aanbid. Hulle is ook van mening dat daar vandag nog ruimte vir erediensbywoning is.

- $42.64 \%$ van die respondente is van mening dat daar vandag nog ruimte vir die bywoon van eredienste is, maar dat eredienste nie noodsaaklik is om God te aanbid nie.

Note: Hierdie artikel is gebaseer op die PhD-proefskrif van M.J. Jansen van Rensburg, getiteld 'Die verband tussen Godsbeeld, liturgiese ervaring en gemeentebou'. Die proefskrif is voorberei onder leiding van prof. Malan Nel en prof. Cas Wepener, Fakulteit Teologie, Universiteit van Pretoria (2015). Ds. M.J. Jansen van Rensburg is predikant van die Nederduitsch Hervormde Gemeente, Delmas. 
TABEL 1: Lidmate se belewenis van God.

\begin{tabular}{|c|c|c|c|c|c|c|c|c|c|c|c|c|c|c|c|c|c|c|}
\hline \multirow[t]{2}{*}{ Lidmaat } & \multicolumn{3}{|c|}{ Liefdevolle vader } & \multicolumn{3}{|c|}{ 'n Regter } & \multicolumn{3}{|c|}{ 'n Vriend } & \multicolumn{3}{|c|}{ 'n Herder } & \multicolumn{3}{|c|}{ Skepper } & \multicolumn{3}{|c|}{ Rots } \\
\hline & $\mathbf{N}$ & $J$ & $T$ & $\mathbf{N}$ & $J$ & $T$ & $\mathbf{N}$ & $J$ & $T$ & $\mathbf{N}$ & $J$ & $T$ & $\mathbf{N}$ & $J$ & $T$ & $\mathbf{N}$ & $\mathrm{J}$ & $T$ \\
\hline \multirow[t]{3}{*}{$\mathrm{Pa}$} & 0 & 51 & 51 & 8 & 43 & 51 & 3 & 48 & 51 & 0 & 51 & 51 & 0 & 51 & 51 & 1 & 50 & 51 \\
\hline & 0.00 & 100.00 & & 15.69 & 84.31 & & 5.88 & 94.12 & & 0.00 & 100.00 & & 0.00 & 100.00 & & 1.96 & 98.04 & \\
\hline & 0.00 & 39.53 & & 33.33 & 40.19 & & 60.00 & 38.10 & & 0.00 & 38.93 & & 0.00 & 38.93 & & 50.00 & 38.76 & \\
\hline \multirow[t]{2}{*}{$\mathrm{Ma}$} & 2 & 63 & 65 & 14 & 51 & 65 & 2 & 63 & 65 & 0 & 65 & 65 & 0 & 65 & 65 & 1 & 64 & 65 \\
\hline & 3.08 & 96.92 & & 21.54 & 78.46 & & 3.08 & 96.92 & & 0.00 & 100.00 & & 0.00 & 100.00 & & 1.54 & 98.46 & \\
\hline \multirow[t]{3}{*}{ Kind } & 0 & 15 & 15 & 2 & 13 & 15 & 0 & 15 & 15 & 0 & 15 & 15 & 0 & 15 & 15 & 0 & 15 & 15 \\
\hline & 0.00 & 100.00 & & 13.33 & 86.67 & & 0.00 & 100.00 & & 0.00 & 100.00 & & 0.00 & 100.00 & & 0.00 & 100.00 & \\
\hline & 0.00 & 11.63 & & 8.33 & 12.15 & & 0.00 & 011.90 & & 0.00 & 011.45 & & 0.00 & 011.45 & & 0.00 & 011.63 & \\
\hline Totaal & 2 & 129 & 131 & 24 & 107 & 131 & 5 & 126 & 131 & 0 & 131 & 131 & 0 & 131 & 131 & 2 & 129 & 131 \\
\hline \multicolumn{19}{|c|}{ Frequency Missing = 3} \\
\hline
\end{tabular}

N, Nee; J, Ja; T, Totaal.

TABEL 2: ' $n$ Vergelyking tussen erediensbywoning en die noodsaaklikhede van eredienste om God te aanbid.

\begin{tabular}{ccccc}
$\begin{array}{c}\text { Is daar nog ruimte vir erediensbywoning } \\
\text { in die moderene tyd? }\end{array}$ & & \multicolumn{2}{c}{$\begin{array}{c}\text { Het ons eredienste nodig om God } \\
\text { te aanbid? }\end{array}$} \\
\hline Ja & Nee & & Nee & Ja \\
\hline 25.00 & 75.00 & & 1.79 & 3.90 \\
\hline 42.64 & 57.36 & & 98.21 & 96.10 \\
\hline
\end{tabular}

TABEL 3: Frekwensie van erediensbywoning.

\begin{tabular}{lcc}
\hline $\begin{array}{l}\text { Hoe gereeld word eredienste } \\
\text { bygewoon? }\end{array}$ & $\begin{array}{c}\text { Getal respondente wat positief } \\
\text { gereageer het }\end{array}$ & Persentasie \\
\hline Weekliks & 89 & 66.42 \\
Twee keer per maand & 39 & 29.10 \\
Een keer elke drie maande & 6 & 4.48 \\
\hline
\end{tabular}

TABEL 4: 'n Vergelyking tussen respondente se beeld van God en die inkleding van eredienste.

\begin{tabular}{lc}
\hline Beeld van God & Eredienste moet streng formeel wees (\%) \\
\hline God is 'n Liefdevolle Vader & 48.48 \\
God is 'n Regter & 49.09 \\
God is 'n Vriend & 46.51 \\
God is 'n Herder & 47.76 \\
God is 'n Skepper & 47.76 \\
God is 'n Rots & 47.73 \\
God is 'n Vuur & 49.43 \\
God is Water & 47.71 \\
God is 'n Versorger & 47.37 \\
\hline
\end{tabular}

Verder is die frekwensie van erediensbywoning ondersoek ten einde 'n aanduiding te kry van hoe lidmate hulle geloof uitleef. Die reaksie was soos volg.

Alhoewel Tabel 2 aantoon dat 96.10\% van die respondente van mening is dat deelname aan die gemeente se eredienste en aktiwiteite belangrik is (vgl. Jansen van Rensburg 2015:246), sien ons dat die werklike bywoning van eredienste nie so hoog is nie.

Die navorsing het 'n vergelyking getref tussen lidmate se beeld van God en die formaat van eredienste in 'n poging om lidmate se liturgiese behoeftes te bepaal.

Uit Tabel 4 se gegewens blyk dit dat die meerderheid respondente, ongeag van die beeld wat hulle van God het,
TABEL 5: 'n Vergelyking tussen respondente se beeld van God en hoe die respondente dink vreemdelinge se ervaring van die eredienste is.

\begin{tabular}{lc}
\hline Beeld van God & Vreemdelinge voel tuis in gemeente (\%) \\
\hline God is 'n Liefdevolle Vader & 89.39 \\
God is 'n Regter & 90.00 \\
God is 'n Vriend & 89.15 \\
God is 'n Herder & 89.55 \\
God is 'n Skepper & 89.55 \\
God is 'n Rots & 89.39 \\
God is 'n Vuur & 88.51 \\
God is Water & 88.99 \\
God is 'n Versorger & 90.23 \\
\hline
\end{tabular}

van mening is dat die eredienste nie streng formeel hoef te wees nie.

Daar is ook ondersoek ingestel na vreemdelinge se ervaring van eredienste. Daar is dus gekyk na lidmate se mening oor hulleself en hoe hulle dink dat mense wat nie deel is van die gemeente nie, die eredienste sal ervaar. Hiermee word die gemeente se gasvryheid getoets.

Tabel 5 toon aan dat lidmate oor die algemeen 'n baie positiewe beeld van hulle eredienste het.

In die lig van die kwantitatiewe navorsingsresultate (Osmer se 'What is going on?'), is dit baie duidelik dat lidmate 'n baie positiewe beeld van God het. As gevolg daarvan moet lidmate begelei word om die inhoud en betekenis van die verskillende metafore van God in die opbou van 'n missionale gemeente te ontgin (Osmer se 'How might we respond?').

\section{Godsbeelde in die Bybel}

Die empiriese navorsing het die antwoord op die vraag 'What is going on?' (Osmer 2008:4) verskaf. In ons teologiese interpretasie poog ons om te verstaan wat gebeur en moet ons antwoorde vind op 'n volgende vraag van Osmer (2008:4), naamlik 'Why is this going on?'. Van der Watt (2000:xvii) is van mening dat 'the presence and reality of God is communicated as a metaphorical event'. Aangesien die verstaan van God uiteenlopend by verskillende mense is, lei dit daartoe dat sekere metafore van God sterker as ander funksioneer. 
Vos en Wepener (2014) is van mening dat:

As ' $n$ metafoor ' $n$ verhouding tussen twee domeine skep, word nuwe assosiasies en verbindings tot stand gebring. 'n Metafoor maak ons oë oop om te sien. Die resultate is meestal verrassend en vreemd. (bl. 97)

Dit lei tot die noodsaaklike transformering van lewens. Ricoeur (1994:111) beskryf metafore as 'change of meaning' waarmee nuwe assosiasies geskep word wat tot nuwe en dieper betekenisse lei.

Aangesien die navorsing vanuit 'n prakties-teologiese perspektief gedoen word met die fokus spesifiek op gemeentebou en met besondere klem op liturgiese vernuwing met die oog op die opbou van die gemeente, wil die artikel geensins poog om 'n volledige eksegese van die verskillende metafore van God te gee nie. Erkenning word aan diepere eksegetiese perspektiewe in die verband gegee, maar dit val buite die skopus van hierdie navorsing.

In ons nadenke oor God, onderskei ons tussen persoonlike en onpersoonlike metafore.

\section{Die persoonlike metafore van God}

\section{God is 'n Herder}

Vanuit die nomadiese verlede van die volk Israel, word die besondere verhouding van Herder en kudde as metafoor (Ps 23) gebruik om die bemoeienis wat God met die volk Israel gemaak het (De Vaux 1973:3), te beskryf. Dit is veral die uitverkiesende genade van God wat hiermee sterk beklemtoon word. Die Herder (God) kies om met hierdie spesifieke kudde (die volk Israel) bemoeienis te maak. Nie net kies God die volk Israel uit al die volkere van die aarde nie, maar God is die Herder wat hulle die toekoms inlei.

Die Evangelieskrywer verwys in Johannes 10:3 na Jesus as die goeie Herder wat die skape uitlei en hiermee word die hegte en besondere verhouding tussen Jesus en die gelowiges beskryf. Barret (1978:374) sien hierin 'the comparison between the ministry of Jesus and the work of a shephard is general, but the messianic shepherding of God's people lies in the background'. Hiervolgens is Jesus dus die Messiaanse Herder wat besondere bemoeienis met sy skape gemaak het om hulle te versorg (vgl. Borchert 1996:327-346).

Met die metafoor van Herder word die besondere band tussen God en mens beklemtoon.

\section{God is Koning}

Dat God as Koning uitgebeeld word, beklemtoon nie slegs die mag en majesteit waarmee Hy heers nie, maar plaas ook die verloop van die ganse geskiedenis in sy hande. Soos wat 'n gewone aardse koning oor sy land en mense regeer en met mag sy koninkryk beskerm, soveel te meer is en bly God in beheer - selfs ook oor die ander nasies:

The God of Israel here controls the destiny not only of his own people but that of another nation in a foreign land. The gods of the Egyptians cannot resist YHWH's power and might. (Mills 1998:31)

Die gebeure rondom die uittog uit Egipte en die hele reis deur die woestyn, ondersteun die metafoor van God as Koning wat met mag en majesteit oor mense en die natuur regeer (Mills 1998:31).

In die Nuwe Testament word die verwysings na God as Koning met die eskatologiese verwagtinge ten opsigte van God in verband gebring. Jesus het verskeie kere na die koninkryk van God verwys, wat impliseer dat God as Koning 'n einde sal maak aan die huidige wêreld soos ons dit ken. Omdat God deur Christus as sy Gestuurde die aardse en tydelike ruimte as die ewige Koning betree het, beteken dit volgens Smith (2003):

Die versekering van God se koningskap en heerskappy bied aan mense die hoop om selfs midde-in verlies hoopvol te lewe en vas te hou aan die bevrydende sorg van God wat hooploses laat leef in die verwagting dat die koninkryk van die andersmagtige koning ook vir hulle bedoel is. (bl.1447)

\section{God is 'n Vader}

Die metafoor van God as Vader bring ook die metafoor van familie na vore en beklemtoon ons verhouding met God, asook ons onderlinge verhouding met mekaar. Hierdie metafoor veronderstel ' $n$ Vader-kind-verhouding en word soos volg deur Nielsen (2005:267) beskryf: 'The relationship between parents and children is so strong that they neither desert nor forget each other. The parent-child metaphor underlines the strong bond between Yahweh and Israel.'

Hierdie verhouding of band tussen God en Israel begin met die roeping van Abram in Genesis 12: 1-3 en is die vertrekpunt van die Vader-kind-verhouding wat in die geskiedenis van die volk Israel ontvou (Keil \& Deliztzch 1983:193).

Die metafoor van God as Vader kry in die Nuwe Testament 'n soteriologiese perspektief (Van der Watt 2000:197) met Christus wat as die Seun van God na die wêreld toe gekom het om met die mag en gesag van die Vader op te tree (Barrett 1978:502). Die gebroke verhouding tussen God en mens word herstel.

\section{God is die Versorger}

Omdat ons met die interafhanklikheid van metafore (Smith 2003:1446, 1458) rekening moet hou, beteken dit dat God as Koning ook Herder en Vader is. As Almagtige en Ewige is Hy Vader en Herder. Hy is dus op versorgende wyse by die skepping betrokke: 'God alone is true Wisdom, and therefore the true Teacher, Guide and Educator' (Barth 1961:247). God is dus die Versorger van sy skepping en sy kinders. Wanneer God in die tuin kom wandel en na die mens soek met die woorde, 'Waar is jy?' (Gen 3:9), dan is God soos 'n Versorger of Terapeut in 'n beradingsessie met die mens wat weens die sondeval wegkruip. Die sondeval het by die mens 'n gevoel van skaamte en mislukking gelaat en God die Versorger gebruik 'n gesprek om die mens vanuit sy nood te begelei. 
Jesus Christus het as Gestuurde van God, maar ook as deel van die Drie-eenheid, mense in hulle nood aangeraak en baie van sy wonders was versorgend en hulpverlenend van aard.

\section{God is 'n Vriend}

Die metafoor van God as Vriend bring ons binne die ruimte van besondere verhoudinge. Smith (2003:1455) sien dit soos volg: 'Die vriendskapsmetafoor impliseer verbond, ver-bond-enheid, ver-bind-tenis, ver-bind-ing, bind-ing - 'n binding van vertroue en verbintenis'.

In hierdie metafoor speel die verbond tussen God en mens 'n belangrike rol. In Johannes 15 vind ons ook 'n besondere verbintenis en verband tussen Jesus en die dissipels (vgl. Borchert 2002:137-167).

\section{God is Liefde:}

Hierdie metafoor beklemtoon dat God vir mense omgee, maar mense ook wil oproep om vir mekaar lief te wees. Die koinonia in die gemeente begin by God wat Liefde is en liefde tussen mekaar wek.

Vir die opbou van die gemeente beteken hierdie metafoor dat God op 'n besondere wyse met die gemeente bemoeienis maak. Dit is 'n bemoeienis van omgee en liefhê wat tot verandering en groei lei.

\section{Die onpersoonlike metafore van God}

Naas die persoonlike metafore wat gebruik word om God te beskryf, wys Nielsen (2005:263) daarop dat daar ook onpersoonlike metafore is, byvoorbeeld God as 'vuur' en God as 'rots'. Nielsen (2005) bring die persoonlike en onpersoonlike metafore in dialoog met mekaar en dit dra by tot 'n beter begrip van God se grootheid en sy andersheid. In hierdie verband is die volgende opmerking van Nielsen (2005) ook belangrik:

The meaning of the impersonal metaphors is to remind us that there is more to be said about God than just saying God is like a human. God transcends the boundries of human life. (bl.264)

Drie van die onpersoonlike metafore wat na God verwys, word vervolgens bespreek.

\section{God is 'n Rots}

Die stabiliteit en standvastigheid wat by God gevind word, word deur hierdie metafoor beklemtoon.

\section{God is Vuur}

Tydens die volk Israel se trek deur die woestyn vind ons God in die vuurkolom (Eks 13:21) wanneer Hy die volk lei. Die vuurtonge wat deel van die Pinkstergebeure was (Hand 2:3-4), word in die Nuwe Testament die metafoor van God, die Heilige Gees. Van der Watt (2000:375) beklemtoon die rol wat die Heilige Gees in die aanbidding van die Vader en die Seun speel en dit bring ons by die sentrale doel van die pneumatologie in die opbou van die gemeente (Nel 2015:91).

\section{God is Water}

Soos wat water die bron van lewe en hoop is, beeld hierdie metafoor God uit as die bron en oorsprong van lewe en hoop. Christus, as die Lewende Water (vgl. Joh 4:13), gee aan die gemeente dít wat noodsaaklik vir groei en lewe is.

Op die vraag van Osmer (2008:4), 'What is going on?', het die empiriese navorsing getoon dat die lidmate van die NHKA 'n baie sterk en positiewe beeld van God het. Osmer (2008:4) se vraag, 'Why is this going on?', het ons gebring by die hermeneutiek van die metafore wat sekerheid en standvastigheid in God voorsien.

\section{Die verskillende Godsbeelde en die invloed daarvan op gemeentebou}

Die empiriese navorsing het getoon dat lidmate 'n baie positiewe beeld van God het wat ' $n$ belangrik vertrekpunt is vir die opbou van 'n missionale gemeente. Dit bring ons by die vraag 'What ought to be going on?' (Osmer 2008:4). Wat behoort dus met die resultate van die empiriese navorsing te gebeur?

Van den Brom (2009:149) is van mening dat 'de gemeenschap van gelovigen die als gemeenschap expressie geeft aan het beeld van God'. Die verskillende metafore van God moet dus gestalte in die gemeentelede se uitleef van hulle roeping vind. Dit word soveel meer noodsaaklik wanneer die veranderende wêreld in aanmerking geneem word. Alhoewel die wêreld onherroeplik verander het, het die mens se soeke na God nie verander nie (Heitink 2012:14). In antwoord op die vraag, 'What ought to be going on?' (Osmer 2008:4), kan ons dan antwoord dat die waarde wat die verskillende metafore van God vir die opbou van die gemeente inhou, ontgin en benut moet word.

Die imperatief om die betekenis van die metafore van God uit te leef, word nóg groter in die postmoderne samelewing waar alles bevraagteken word en daar 'n verskuiwing plaasgevind het van 'n Christendom of Christelikheid as instituut na 'n era waar geloof baie meer individualisties en persoonlik ervaar word (Niemandt 2007:14). In sekere gevalle wil dit selfs voorkom asof geloof en aanbidding besig is om uit die publieke oog te verdwyn. Taylor (2007:539) vra die eenvoudige vraag: 'Why is it so hard to believe in God in (many milieus of) the modern West, while in 1500 it was virtually impossible not to?' Wat dus moet gebeur, is dat die metafore van God inhoud en betekenis in die missionale opbou van die gemeente moet vind.

Alhoewel die empiriese navorsing op verskeie metafore gefokus het, word slegs enkele van die metafore se invloed op die opbou van 'n missionale gemeente bespreek.

\section{Herder}

As Herder versorg God die gemeente as 'n kudde en daar ontstaan 'n besondere gemeenskap tussen hulle (Ps 23). 
Hierdie gemeenskap verwys na die ekklesiologiese modelle van Dulles (2002:7) en dan spesifiek na die kerk as mistieke gemeenskapsmodel waar die klem en fokus op die koinonia van die gemeente val.

\section{Koning}

Die metafoor van God as Koning beteken daar is hoop te midde van lyding en swaarkry in die gebroke wêreld waarin ons ons bevind. Vanuit 'n gemeentebou-perspektief gee dit standvastigheid en rigting aan die gemeentelede wat in onseker tye soekend na leiding is. Van der Watt (2000:377) wys daarop dat die gelowiges in Christus deel van die koninkryk van God geword het, wat die soteriologie van die metafoor beklemtoon.

\section{Vader}

Soos wat 'n vader sy gesin versorg, so versorg God as Vader die gelowiges en word die gemeente opgebou. Die koinonia is die sigbaarwording van God as Vader wat met die sondige mens bemoeienis maak. Alhoewel die empiriese navorsing wat in die NHKA se Ring van Laeveld gedoen is, getoon het dat $98.5 \%$ van die respondente ' $n$ baie positiewe ervaring van God as Vader het (Jansen van Rensburg 2015:239), kan die metaforiese verwysing na God as Vader problematies wees vir iemand wat nie 'n positiewe vaderbeeld het nie.

\section{Versorger}

Die versorgende liefde van God vir die gemeente is belangrik vir die opbou daarvan, aangesien die gemeente die ruimte is waarin God se liefde en omgee vir die wêreld sigbaar moet word (Nel 1994:34; 2015:47).

Die bediening moet dus nie na binne gerig wees soos byvoorbeeld op instandhouding nie, maar eerder op die uitdra van die boodskap van die nabyheid van God se koninkryk (Van den Brom 2009:138). Vir Keifert (2013:37) is dit ook belangrik dat die gemeente na sy roeping en doel in die gemeenskap sal vra. Op hierdie wyse gebruik God die gemeente om sy versorgende liefde sigbaar te maak. Nel (2015:38) beskryf die gemeente soos volg: 'Congregations are indeed his chosen vehicles to the world.' Dit is om hierdie rede van soveel meer belang dat die metafoor van God se versorgende liefde in die gemeente se missionale opbou sigbaar sal word.

\section{Godsbeelde en liturgie}

As 'n verdere deel van die antwoord op die vraag, 'What ought to be going on?' (Osmer 2008:4), verskuif die fokus na die erediens as 'n ontmoetingsgebeurtenis tussen God en die mens (Nel 2015:16). Die invloed wat lidmate se Godsbeeld op hulle liturgiese handelinge in die erediens het, vorm 'n belangrike deel van die opbou van 'n missionale gemeente. Barnard (1985) is van mening dat liturgie wyer strek as net die erediens. Volgens hom omvat dit:

die hele lewe en geskied [dit] in die daaglikse lewe; dit is die allesomvattende en insluitende diens aan God. Dit handel oor alles in en om die erediens en soos dit in die lewe gerealiseer word. (bl.52)

Volgens Barnard (1985:52) omvat die begrip liturgie die preek, die nagmaal, die doop, die openbare belydenis van geloof, die bevestiging van ampsdraers, gebedsdienste, Bybelstudie, huweliksdienste sowel as die verskillende elemente van die erediens. Dit sluit ook die kerkgebou en die dinamiek van die erediens in. Dit is dus die allesomvattende dien van die Here wat die totale inhoud en betekenis van al die metafore van God sigbaar maak.

In antwoord op Osmer (2008:4) se vraag 'What ought to be going on?', moet die erediens só ingerig word dat liturgie sigbaar gestalte aan die verskillende metafore van God sal gee om sodoende tot die missionale opbou van die gemeente by te dra.

Ook Calvyn beskou liturgie as, 'niet alleen in de kerk is er de dienst van God, maar evenzeer in het dagelijks bedrijf van ons mensen' (Brienen 1987:175). Vir Calvyn is liturgie en etiek aan mekaar verbonde, aangesien dít wat op 'n Sondag in die erediens gebeur, deurwerk na dít wat in die week gelewe word. Aanbidding in die erediens vloei dus oor na die lewe van elke dag. Sodoende kry ons die erediens van die lewe wat daarop fokus om getuies van God se almag te wees (De Klerk 2007:29).

Wepener (2012) plaas liturgie binne die raamwerk van 'Liturgiese Studies' en hieronder verstaan hy:

The complete enacted ritual performance in which both God and humans are involved, which entails much more than only what one finds in written documents such as prayer books. Thus both the worshipper and the One being worshipped serve as objects of study in liturgical research. (bl.113)

Naas die gebruik van woorde word sakramente as kommunikasiemiddel gebruik, aangesien die Woord en woorde aan die nagmaaltafel sigbaar word (Wepener 2010:29). Die sakrament van die nagmaal, veral die gebruik van die NHKA om by die tafel aan te sit, kan verder sigbaar gestalte aan die metafore van God gee as:

- Vader: God ontmoet die gemeente as sy kinders om die tafel.

- Herder: God voed die gemeente as sy kudde om die tafel.

- Versorger: God vertroos en versterk die gemeente met die sakrament van die nagmaal wat teken en seël van sy genadeverbond is.

- Liefde: Die sakrament van die nagmaal is 'n teken en seël van God se liefde wat Christus aan die kruis oorwin het.

Vos (1999:102) gaan van die standpunt uit dat liturgie agnosme bestry, aangesien dit die ruimte bied waar God en mens mekaar ontmoet. Dit sluit ' $n$ wye verskeidenheid liturgiese handelinge en gebeure in, byvoorbeeld taal en verhale as gesproke verkondiging (Vos 1999:108, 109), maar ook sigbare verkondiging wanneer liturgie as maaltyd beskryf word (Vos 1999:111). Christus maak verkondiging 
sigbaar as Hy die Paasfees met nuwe inhoud vul deur die brood en wyn as simbole van die nagmaal aan die dissipels te gee met die opdrag dat dit as verkondiging van die evangelie gevier moet word. Op hierdie wyse word die opbou van ' $n$ missionale gemeente die sigbaarmaking van God in die wêreld.

\section{Hoe moet ons op 'n veranderende wêreld reageer?}

In 'n veranderende wêreld waar die gevolge van sekularisasie al hoe duideliker word en transformasie ten opsigte van aanbidding 'n realiteit is, is Van der Merwe (2013:14) van mening dat 'die status quo eenvoudig nie in 'n post-sekulêre wêreld gehandhaaf [kan] word nie'. Dit bring ons by die vraag, 'How might we respond?' (Osmer 2008:4). Hoe kan ons op die resultate van die empiriese navorsing reageer?

Die empiriese navorsing het getoon dat, alhoewel lidmate se beeld van God baie positief is, slegs $57.17 \%$ van die respondente die bywoning van eredienste om God te aanbid as noodsaaklik beskou. Hoe moet ons daarop reageer, veral as $97.01 \%$ van die respondente van mening is dat daar nog ruimte vir die bywoning van eredienste is? Dit verwoord iets van die verandering wat plaasgevind het, aangesien daar nog ruimte en plek vir eredienste is, maar dat dit nie as noodsaaklik vir aanbidding beskou word nie. Om God te aanbid, is dus noodsaaklik, maar eredienste word nie meer beskou as die plek en ruimte waarbinne dit gedoen moet word nie.

Snyder (2001:21) verwys na Bultman wat van die 'Third Church' gepraat het en daarmee na die verandering van die kerk verwys. Hiervolgens kan afgelei word dat, alhoewel die bestaande wyse van aanbidding in tradisionele hoofstroomkerke onder druk is en in sekere gevalle besig is om af te neem, dit nie noodwendig beteken dat alle kerke besig is om te kwyn nie. Keifert (2013:18) maak die opmerking dat kerke en gemeentes wat vroeër baie prominent was en leierskaprolle in 'n bepaalde gemeenskap gespeel het, besig is om minder prominent te word, terwyl ander kerke weer na vore kom.

Ook moet die invloed wat globalisering en die verspreiding van inligting deur middel van die televisie en die Internet op die verkleining van die wêreld het, nie misgekyk word nie. Daarmee saam het die gebeure van 11 September 2001 in Amerika 'n wêreldwye invloed op die mensdom ontketen. Voeg hierby die migrasie van mense oor kontinente, wat die ontstaan van nuwe gemeenskappe tot gevolg het: 'De komst van vreemdelingen en met name van de Islam in de Westerse samenleving, zichbaar in de bouw van moskeeën en in kleding zoaals hoofddoekjes, roept veel weerstand op' (Heitink 2012:204-205).

Die gevolg hiervan is 'n verandering wat nie slegs ingrypende gevolge vir die kerk het nie, maar ook nuwe moontlikhede en uitdagings aan die kerk bied. Nie slegs het die godsdienstige landskap verander nie, maar sekularisasie het ook 'n besliste invloed op die beoefening van godsdiens (Heitink 1999:43). Baie mense beskou hulleself nog as gelowiges, maar is kerklik onbetrokke. In hierdie opsig praat Heitink (2012:218) van 'religie zonder kerk', wat die verleentheid maar ook die geleentheid van die kerk verwoord.

Dit laat die vraag ontstaan of dit die einde of die begin vir die kerk is: 'How might we respond?' (Osmer 2008:4). Gegewe die ekklesiologiese uniekheid van elke gemeente, moet geleenthede ontgin word om die inhoud en betekenis van die verskillende metafore van God deel van die lewensliturgie te maak. As draer van die Evangelie van hoop, is elke gemeente 'n openbare vertoonvenster van God (vgl. Nel 1994:11; 2015:43). Die uitdaging waarmee die kerk te doen het, is dat baie mense met hulle rug na die vertoonvenster staan (Nel 1994:11). Gelowiges moet daarom begelei word om 'n groter missionale bewussyn te ontwikkel ten einde hulle identiteit as beelddraers van God uit te leef en die eksistensiële waarde van die metaforiese uitbeelding van God in die wêreld sigbaar te maak.

In 'n post-sekulêre era (King 2009:11) moet gemeentes en lidmate missionaal begelei word om die verskillende metaforiese beelde van God beter te verstaan en uit te leef. Post-sekularisasie bied nuwe uitdagings en geleenthede wat benut kan word deur die inhoud en betekenis van die verskillende metaforiese uitbeeldings van God sigbaar te maak.

\section{Erkenning Mededingende belange}

Die outeur verklaar dat hy geen finansiële of persoonlike verbintenis het met enige party wat hy nadelig of voordelig kon beïnloed het in die skryf van hierdie artikel nie.

\section{Literatuurverwysings}

Barnard, A.C., 1985, Die erediens, NG Kerkboekhandel, Pretoria.

Barrett, C.K., 1978, The Gospel according to St.John: An introduction with commentary and notes on the Greek text, 2nd edn., William Clowes Ltd., Beccles, London.

Barth, K., 1961, Church dogmatics: The doctrine of the creation, vol. 3, part 4, transl. G.W. Bromiley \& T.F. Torrance, T\&T Clark, Edinburgh.

Borchert, G.L., 1996, 'John 1-11', in E.R. Clendenen (ed.), The New American Commentary, vol. 25A, pp. 327-346, Broadman \& Holman Publishers, Nashville, TN.

Borchert, G.L., 2002, 'John 12-21', in E.R. Clendenen (ed.), The New American Commentary, vol. 25B, pp. 137-167, Broadman \& Holman Publishers, Nashville, TN.

Brienen, T., 1987, De liturgie bij Johannes Calvijn: Zijn publicaties en zijn visies, Uitgeverij De Groot Goudriaan, Kampen.

De Klerk, B., 2007, 'Liturgie en evangelisasie met besondere verwysing na die seën', Praktiese Teologie in Suid Afrika 22(2), 20-39.

De Vaux, R., 1973, Ancient Israel: Its life and institutions, Darton, Longman \& Todd, Londen.

Dulles, S.J., 2002, Models of the Church, Image Books, Doubleday, New York.

Heitink, G., 1999, Practical theology, Wm. B. Eerdmans Publishing Company, Grand Rapids, MI.

Heitink, G., 2012, Golfslag van de tijd: Europa's niet te stillen verlangen naar God, Uitgeverij Kok, Utrecht.

Jansen van Rensburg, M.J., 2015, Die verband tussen Godsbeeld, liturgiese ervaring en gemeentebou, PhD-verhandeling, Universiteit van Pretoria, Pretoria.

Keifert, P.R., 2013, Ons is nou hier: 'n Nuwe era van gestuur-wees: 'n Missionale ontdekkingsreis, Bybel-Media, Wellington.

Keil, C.F. \& Delitzsch, F., 1983, Commentary on the Old Testament in ten volumes: The Pentateuch, vol. 1, Wm. B. Eerdmans Publishing Company, Grand Rapids, MI. 
King, M, 2009, Postsecularism: The hidden challenge of extremism, James Clark \& Co, Cambridge.

Mills, M.E., 1998, Images of God in the Old Testament, Wellington House, London Nel, M., 1994, Gemeentebou, Orion Uitgewers, Halfway House.

Nel, M., 2015, Identity - driven churches, Biblecor, Wellington.

Nielsen, K., 2005, Metaphor in the Hebrew Bible, Leuven University Press, Leuven.

Niemandt, N., 2007, Nuwe drome vir nuwe werklikhede, Lux Verbi.BM, Wellington.

Osmer, R.R., 2008, Practical theology: An introduction, Wm. B. Eerdmans Publishing Company, Grand Rapids, MI.

Ricoeur, P., 1994, The rule of metaphor: Multi-disciplinary studies of the creation of meaning in language, Routledge, London.

Smith, W.J., 2003, 'Godsbeelde in die konteks van die rouproses', HTS Teologiese Studies/Theological Studies 59(4), 1443-1460. https://doi.org/10.4102/hts. v59i4.703

Snyder, H.A., 2001, Models of the kingdom, Wipf \& Stock Publishers, Eugene, OR
Taylor, C., 2007, A secular age, The Belknap Press of Harvard University Press, London. Van den Brom, L., 2009, Kerk als gemeenschap: Beeld van God', in G. Immink (ed.), God in 'n kantelende wêreld, pp. 136-152, Protea Boekhuis, Pretoria.

Van der Merwe, J.C., 2013, 'Lense op spiritualiteit en kerkwees: Die pad vorentoe vir die Nederduitsch Hervormde Kerk van Afrika (NHKA)', HTS Teologiese studies/ Theological Studies 69(1), 1-16.

Van der Watt, J.G., 2000, Family of the King: Dynamics of metaphor in the Gospel according to John, Brill, Leiden.

Vos, C.J.A., 1999, Die towertyd van liturgie', Praktiese Teologie in Suid Afrika 14(1), 99-126.

Vos, C. \& Wepener, C., 2014, Tussen God en mens: 'n Literêr-estetiese benadering tot liturgie en prediking in 'n skuiwende kultuur, Hond Uitgewers, Pretoria.

Wepener, C., 2010, Aan die tafel met Jesus, Bybel-Media, Wellington.

Wepener, C., 2012, 'Reflections on recent developments in liturgical studies in the light of experiences from the research field and the lecture room', Journal of Theology for Southern Africa 144, 109-143. 